\title{
Antioxidant and pancreatic lipase inhibitory activities of Anemarrhena asphodeloides
}

\author{
O Jun Kwon ${ }^{1}$, Ha Yeong Lee ${ }^{2}$, Tae Hoon $\mathrm{Kim}^{2,3}$, Se Gie $\mathrm{Kim}^{4} *$ \\ ${ }^{1}$ Daegyeong Institute For Regional Program Evaluation, Gyeongsan 712-210, Korea \\ ${ }^{2}$ Department of Herbal Medicinal Pharmacology, Daegu Haany University, Gyeongsan 712-715, Korea \\ ${ }^{3}$ Blue-Bio Industry RIC, Dongeui University, Busan 614-714, Korea \\ ${ }^{4}$ Department of Pharmaceutical Science and Technology, Catholic University of Deagu, Gyeongsan 712-702, Korea
}

\section{지모 추출물의 항산화 및 pancreatic lipase 저해 활성 평가}

\author{
권오준 ${ }^{1} \cdot$ 이하영 ${ }^{2} \cdot$ 김태훈 $^{2,3}$ • 김세기 ${ }^{4} *$ \\ ${ }^{1}$ 대경지역평가단, ${ }^{2}$ 대구한의대학교 한약재약리학과, ${ }^{3}$ 동의대학교 블루바이오소재개발 및 실용화 지원센터, \\ ${ }^{4}$ 대구가톨릭대학교 제약산업공학과
}

\begin{abstract}
In this study, the antioxidant and pancreatic lipase inhibitory activities of aqueous methanolic (70\% methanol) extract from the roots of Anemarrhena asphodeloides were investigated. The extracts of four solvent fractions (the n-hexane layer, EtOAc layer, $\mathrm{n}-\mathrm{BuOH}$ layer, and $\mathrm{H}_{2} \mathrm{O}$ layer) of the $\mathbf{7 0} \%$ methanol extract were also investigated. Furthermore, the total phenolic content was quantified using a spectrophotometric method. All the tested samples showed dose-dependent radical scavenging and pancreatic lipase inhibitory activities. In particular, the pancreatic lipase inhibitory activity of the ethyl acetate soluble portion (the EtOAc layer) from the hizomes of the $A$. asphodeloides was higher than that of the other solvent-soluble portions. The antioxidant property of the extracts was evaluated using radical scavenging assays with DPPH and $\mathrm{ABTS}^{+}$radicals. $1000 \mathrm{mg} / \mathrm{ml}$ of the $\mathrm{n}$-BuOH layer extract showed 91.2\% DPPH radical scavenging activity. The EtOAc layer extract and the n-BuOH layer extract showed $\mathrm{IC}_{50}=$ $20.5 \pm 1.7 \mathrm{mg} / \mathrm{ml}$ and $\mathrm{IC}_{50}=\mathbf{5 0 . 5} \pm 0.7 \mathrm{mg} / \mathrm{ml} \mathrm{ABTS}^{+}$radical scavenging activities, respectively. The anti-obesity efficacy of the $A$. asphodeloides extract was tested via porcine pancreatic lipase assay. A pancreatic lipase inhibitory activity $\left(\mathrm{IC}_{50}\right)$ of $31.3 \pm 0.1 \mathrm{mg} / \mathrm{ml}$ was obtained from the EtOAc layer extract. These results suggest that $A$. asphodeloides can be considered a new potential source of natural antioxidant and anti-obesity agents.
\end{abstract}

Key words : Anemarrhena asphodeloides, antioxidant activity, DPPH, ABTS ${ }^{+}$, pancreatic lipase

\section{서 론}

현대 사회 속의 여러 가지 요인들에 의해 인체의 산화촉 진물질(prooxidant)과 산화억제물질(antioxidant)간의 균형 이 깨져 산화 촉진이 과하게 일어나면 산화적 스트레스가 유발된다(1). 최근 이러한 산화적 스트레스와 관련된 각종 퇴행성 질환 및 생활 습관성 질병이 사회적 문제로 대두되 고 있으며 그 원인은 활성산소로 알려져 있다(2). Superoxide, nitric oxide, nitrogen dioxide, hydroxyl,

*Corresponding author. E-mail : sgkim7@cu.ac.kr

Phone : 82-53-850-2564, Fax : 82-53-359-6823 peroxynitrite 등과 같은 활성산소 종(Reactive Oxygen Species, ROS)들은 인간의 대사과정 중에 끊임없이 발생되 며 불안정하고 반응성이 높아 여러 생체물질과 쉽게 반응하 고, 체내 고분자들을 공격하여 세포와 조직에 비가역적인 손상을 일으키거나 돌연변이, 세포독성 및 발암 등을 초래 하게 된다 $(3,4)$. 체내에서 ROS나 free radical이 DNA를 공격 하거나, 지질을 산화시키기 전에 그들을 중화시켜 노화방 지, 성인병 예방 등의 기능을 하는 것이 항산화물질이 다. $(5,6)$. 현재 널리 사용되고 있는 항산화제는 butylated hydroxy anisol(BHA) 및 butylated hydroxy toluene(BHT) 등 의 합성 항산화제이며, 이들을 $50 \mathrm{mg} / \mathrm{kg} /$ day 이상의 고용량 
으로 장기간 복용 시 지질대사의 불균형과 암을 유발시킬 수 있으므로 사용을 제한을 권고하고 있다(7). 이러한 합성 항산화제를 대체할 수 있는 우수한 소제의 개발이 요구되고 있으며, 최근에는 각종 천연소재 등에서 보다 안전하고 항 산화효과가 뛰어난 천연 항산화제를 개발하기 위한 많은 연구가 활발하게 이루어지고 있다(8).

최근 서구화된 식습관과 잘못된 생활습관에 의해 체중과 다 및 비만인구가 급격히 증가하고 있다. 비만은 섭취에너 지와 소비에너지의 불균형에 의한 에너지 대사이상으로 지방세포에 중성지방이 과도하게 축적된 상태이다(9). 비 만의 가장 큰 원인은 고열량이나 고지방을 함유한 음식의 섭취 및 운동 부족으로 인한 과도한 체내지방 축적이지만, 이외에도 신경내분비 계통의 이상, 약물, 유전적 요인 및 생화학적 이상반응에 의해서도 유발되는 것으로 보고되고 있다(10). 이러한 비만은 단순한 외형상의 문제 외에도 고혈 압 및 고지혈증, 제 2형 당뇨병(11), 고혈압, 심장질환, 뇌졸 중, 관절염, 동맥경화(12), 암, 대사증후군, 수면무호흡증, 골관절념, 요통 등의 만성질환과 밀접한 연관이 있다(13). 비만의 치료와 예방에 있어서 식이요법을 동반한 운동이 가장 적절한 방법이나 최근에는 식욕억제제, 지방흡수 억 제제의 개발이 진행되고 있다. 그중에서도 triglyceride를 2-monoacylglycerol과 fatty acid로 분해하는 key enzyme으 로 작용하는 지방분해효소인 pancreatic lipase의 작용을 억 제하는 방법이 주목을 받고 있다(14). 대표적인 pancreatic lipase inhibitor로는 현재 항비만 의약품으로서 시판중인 lipstatin의 유도체인 tetrahydrolipstatin(orlistat)은 Streptomyces toxitricini로부터 유래된 것으로 체내에 섭취된 지방의 약 $30 \%$ 를 소화 흡수하지 않고 배설 해낼 정도로 효능이 매우 우수하다(16). 그러나 최근 위장장애, 과민증, 담즙분비장 애, 지용성 비타민 흡수억제 등의 부작용이 있는 것이 보고 됨에 따라 보다 부작용이 적은 새로운 항비만 물질의 개발 이 요구되고 있다 $(15,17)$. 최근에는 천연소재로부터 pancreatic lipase 저해제 개발을 위한 연구가 활발하게 진행 되고 있으 며(18), 솔체꽃(Scabiosa tschiliensis), 부채마(Dioscorea nipponica), 망고(Mangifera indica)등의 천연 식물로부터 지 방분해 효소를 억제하는 활성성분이 보고되었다(19). 본 연구팀에서도 천연물 유래의 항비만 선도물질 개발의 일환 으로 천연소재 및 천연물에 생물전환기법을 적용하여 pancreatic lipase 저해제를 분리하여 그 효능에 대해 보고하 였다(20,21).

지모는 백합과(Liliaceae)에 속하는 여러해살이풀로서 중 국이 원산지이며 한국과 일본에서도 재배된다. 봄과 가을 에 3년생을 채취하여 근경을 건조한 것을 약용으로 사용한 다, 지모의 근경은 예로부터 진통, 항당뇨, 항염증, 해열, 항균, 이뇨제 등으로 이용되어 왔다(22). 지모에 함유된 성 분으로서는 xanthone, norlignan, steroidal saponin 등의 존재 가 보고되어 있으며(23-25), 항당뇨(26), 항암(27), 항산화,
항균, 항우울 등의 작용이 알려져 있다(28).

본 연구에서는 약용식물로부터 항산화 및 pancreatic lipase 저해활성을 나타내는 천연소재를 탐색하고자 국내 의 자생식물을 대상으로 효능을 평가하였으며, 그중에서 우수한 저해능을 나타낸 지모의 $70 \% \mathrm{MeOH}$ 추출물 및 각 분획물에 대하여 강한 라디칼 소거능 및 pancreatic lipase 저해능을 확인하였기에 그 결과를 보고하고자 한다.

\section{재료 및 방법}

재 료

본 실험에 시료로 사용한 지모(Anemarrhena asphodeloides) 는 2011년 10월 경 채취하여 건조한 것을 2012년 2월에 대구시 소재 약업사에서 구입하여 잘게 세절한 다음 사용하 였으며, 표본시료는 대구한의대학교 한약재약리학과 천연 물화학실험실에 보관하고 있다.

\section{추출물의 제조 및 분획}

건조된 지모 $12 \mathrm{~kg}$ 을 잘게 자른 후 $70 \%$ methyl alcohol $(\mathrm{MeOH}) 42 \mathrm{~L}$ 로 3일간 3회 반복 추출한 후 얻어진 용액을 여과한 후, 감압 농축하여 얻어진 추출물 $(3.4 \mathrm{~kg})$ 에 대해 항산화 효능의 평가로 이용된 $\mathrm{DPPH}$ 및 $\mathrm{ABTS}^{+}$라디칼에 대해서 $1000 \mathrm{mg} / \mathrm{mL}$ 의 시험농도에서 각각 $81.5 \%$ 와 $57.8 \%$ 의 소거능을 나타내었고, pancreatic lipase 저해효능을 평가 한 결과 $1000 \mathrm{mg} / \mathrm{mL}$ 의 농도에서 $74.3 \%$ 의 저해능을 나타내 었다. 활성부분에 함유되어 있는 활성물질의 형태를 추정 하기 위해 농축 결과물 $3.4 \mathrm{~kg}$ 을 물에 현탁하여 저극성 용매 인 n-Haxane 으로 먼저 추출한 후 수층을 다시 ethyl acetate (EtOAc), n-butyl alcohol(n-BuOH)을 이용하여 각각 순차적 으로 3 회 분획하여 추출하였다. 각 용매추출 분획을 감압 농축하여 건조 시킨 후 $\mathrm{n}$-Haxane 가용분획 $(22.9 \mathrm{~g}), \mathrm{EtOAc}$ 가용분획(143.0 g), n- $\mathrm{BuOH}$ 가용분획 $(841.0 \mathrm{~g}), \mathrm{H}_{2} \mathrm{O}$ 가용분 획 $(1.2 \mathrm{~kg})$ 을 각각 얻었으며 각 분획물을 대상으로 라디칼 소거능 및 지방분해효소 저해능을 평가하였다.

\section{$\mathrm{DPPH}$ 라디칼소거능 측정}

지모 $70 \%$ methanol 추출물의 전자공여능은 Blois 방법 (29)에 따라 측정하였다. 각 시료용액에 $120 \mu 1$ 에 $0.45 \mathrm{mM}$ 의 희석한 1,1-diphenyl-2-picrylhydrazyl(DPPH) 용액 $60 \mu \mathrm{l}$ 을 넣고 교반한 후 15 분간 방치한 다음 $517 \mathrm{~nm}$ 에서 흡광도를 측정하였다. 이때 대조물질로는 (+)-catechin를 사용했으며 전자공여능은 시료용액의 첨가군과 무첨가군의 흡광도 차 이를 백분율로 나타내었다.

\section{$\mathrm{ABTS}^{+}$라디칼 소거능 측정}

지모 $70 \%$ methanol 추출물의 2,2'-azinobis-3- ethylben- 
zothiazoline-6-sulfonic acid(ABTS) radical 소거능을 $\operatorname{Re}(30)$ 의 방법을 변형하여 다음과 같이 측정하였다. $7 \mathrm{mM} \mathrm{ABTS}$ (in water)와 $2.4 \mathrm{mM} \mathrm{K}_{2} \mathrm{O}_{8} \mathrm{~S}_{2}$ 동량을 혼합 후 실온, 암소에서 12 시간 방치하여 라디칼의 생성을 유도한 후 $\mathrm{ABTS}^{+}$라디 칼 용액을 희석하여 $734 \mathrm{~nm}$ 에서 흡광도 값이 0.6-0.7 정도가 되도록 희석하여 사용하였다. 희석한 $\mathrm{ABTS}^{+}$라디칼 용액 $100 \mu \mathrm{l}$ 와 생약 추출액 $100 \mu \mathrm{l}$ 을 혼합하여 실온에서 7 분간 반응시킨 후 $734 \mathrm{~nm}$ 에서 흡광도를 측정하였다. 이때 대조 물질로는 (+)-catechin를 사용하였으며 결과는 시료를 처리 하지 않은 군에 대한 \%로 표시하였다.

Pancreatic lipase 저해활성 측정

Pancreatic lipase 저해활성 측정은 $\mathrm{Kim}$ 등(31)이 행한 방 법을 변형하여 실시하였다. 즉 enzyme buffer(10 mM MOPS, $1 \mathrm{mM}$ EDTA, $\mathrm{pH}$ 6.8)에 porcin pancreatic lipase를 $0.5 \mathrm{~g} / 200 \mathrm{~mL}$ 의 농도로 $4^{\circ} \mathrm{C}$ 에서 용해한 후 $4000 \mathrm{rpm}$ 으로 원심분리하여 상층액을 사용하여 $169 \mathrm{uL}$ Tis buffer(100 $\mathrm{mM}$ Tris-HCl, $5 \mathrm{mM} \mathrm{CaCl}, \mathrm{pH}$ 7.0) 와 $6 \mathrm{uL}$ enzyme buffer를 혼합하였다. 샘플은 distilled water로 용해하여 다양한 농도 로 희석하여 사용하였다. 기질로 p-nitriphenyl butyrate (p-NPB)을 $10 \mathrm{mM}$ 이 되게 $\mathrm{DMF}$ 에 용해한 후 enzyme과 sample을 먼저 $37^{\circ} \mathrm{C}$ 에서 15 분 동안 shaking incubation 시킨 후 기질을 첨가 하여 $37^{\circ} \mathrm{C}$ 에서 30 분 동안 shaking incubation 시켰다. $405 \mathrm{~nm}$ 에서 ELISA reader를 이용하여 흡광도를 측정하였다. Pancreatic lipase 저해활성은 시료용액의 첨가 군과 무첨가군의 흡광도 감소율로 나타내었다.

\section{총페놀성 화합물 함량 평가}

총 페놀성 화합물의 함량은 Folin-Denis 방법(32)에따라 측정하였으며, 추출물 혹은 분획물을 $1.0 \mathrm{mg} / \mathrm{ml}$ 농도로 조 제한 후, $75 \mathrm{ml}$ 의 증류수가 함유된 $100 \mathrm{ml}$ 의 시험관에 1 $\mathrm{ml}$ 넣고 잘 혼합하여 Folin-Denis 시액 $5 \mathrm{ml}$ 와 탄산나트륨 포화용액 $15 \mathrm{ml}$ 를 차례로 넣은 다음 이것을 잘 혼합하여 실온에서 60 분 방치한 후, UV/VIS 분광광도계로 $640 \mathrm{~nm}$ 에
서 흡광도를 측정하였으며, 표준물질은 tannic acid를 이용 하여 표준곡선을 작성하여 양을 환산하였다.

\section{결과 및 고찰}

\section{$\mathrm{DPPH}$ 라디칼 소거활성}

$\mathrm{DPPH}$ 는 생체 내에 존재하는 라디칼은 아니지만 그 자체 가 홀수전자를 갖고 있어 $517 \mathrm{~nm}$ 에서 강한 흡광도를 나타 낸다. 따라서 항산화능이 있는 물질과 반응하게 되면 안정 한 형태로 돌아가면서 흡광도 값이 감소한다(33). Table 1에 서 나타낸 것처럼 지모 $70 \%$ methanol 추출물 및 각 유기용 매 분획에 대해서 라디칼 소거능을 평가한 결과, 1000 $\mathrm{mg} / \mathrm{ml}$ 의 농도에서 methanol 추출물이 $81.5 \%$ 의 라디칼 소거 능을 나타내었으며, 특히 $\mathrm{n}-\mathrm{BuOH}$ 분획물이 $1000 \mathrm{mg} / \mathrm{ml}$ 의 농도에서 $91.2 \%$ 의 가장 우수한 라디칼 소거능을 나타내었 으며, 이 결과는 positive control로 사용된 녹차의 항산화 성분으로 잘 알려져 있는 (+)-catechin과 같은 농도에서 비 교한 결과이다. EtOAc 분획물 또한 $1000 \mathrm{mg} / \mathrm{ml}$ 의 농도에서 $87.6 \%$ 의 우수한 라디칼 소거능을 나타내었지만, $\mathrm{H}_{2} \mathrm{O}$ 층에 서 매우 약한 라디칼 소거능을 나타내었다. 또한 n-Hexane 분획물은 라디칼 소거능이 없는 것으로 보여졌다. $\mathrm{DPPH}$ 라디칼 소거능과 총 페놀성 화합물의 함량사이에는 밀접한 상관관계가 있다는 보고(34)에 근거하여 지모의 항산화 활 성과 페놀성 화합물의 연관성을 평가한 결과, Table 1 과 Fig. 2에서 나타낸 것처럼, DPPH 라디칼 소거능은 페놀성 화합물의 함량이 상대적으로 높은 $\mathrm{n}-\mathrm{BuOH}$ 층과 $\mathrm{EtOAc}$ 층에서 가장 높은 것을 확인할 수 있다.

\section{$\mathrm{ABTS}^{+}$라디칼 소거능 측정}

$\mathrm{Re}$ 의 방법(30)을 변형하여 $7 \mathrm{mM} \mathrm{ABTS}$ 와 $2.4 \mathrm{mM} \mathrm{K}_{2} \mathrm{O}_{8} \mathrm{~S}_{2}$ 동량을 혼합한 후, 실온, 암소에서 12시간 방치하여 라디칼 의 생성을 유도한 후, $\mathrm{ABTS}+$ 라디칼 소거능을 측정하였다. 그 결과 Table 2에서 보는 것처럼 지모 $70 \%$ methanol 추출물

Table 1. DPPH radical scavenging activity of the methanolic extract of Anemarrhena asphodeloides and its n-hexane, EtOAc-, n-BuOH-, and $\mathrm{H}_{2} \mathrm{O}$-soluble portions

\begin{tabular}{|c|c|c|c|c|c|c|c|}
\hline \multirow{2}{*}{ Conc. (mg/mL) } & \multicolumn{6}{|c|}{ Scavenging activity $(\%)^{1)}$} & \multirow{2}{*}{$\begin{array}{c}\mathrm{IC}_{50} \\
(\mathrm{mg} / \mathrm{ml})\end{array}$} \\
\hline & 1000 & 500 & 250 & 125 & 62.5 & 31.3 & \\
\hline $70 \% \mathrm{MeOH}$ ext. & 81.5 & 61.3 & 42.1 & 22.8 & 11.9 & 5.4 & $335.5 \pm 7.5$ \\
\hline $\mathrm{n}$-Hexane layer & 3) & - & - & - & - & - & $>1000$ \\
\hline EtOAc layer & 87.6 & 77.0 & 64.2 & 48.6 & 34.4 & 19.2 & $134.4 \pm 1.4$ \\
\hline $\mathrm{n}$-BuOH layer & 91.2 & 82.1 & 70.9 & 50.7 & 32.9 & 22.4 & $118.2 \pm 4.1$ \\
\hline $\mathrm{H}_{2} \mathrm{O}$ layer & 32.2 & 19.9 & 8.8 & 1.1 & 7.0 & - & $>1000$ \\
\hline$(+)$-Catechin ${ }^{2}$ & 93.8 & 93.6 & 93.4 & 93.5 & 88.1 & 72.2 & $17.0 \pm 1.0$ \\
\hline
\end{tabular}

${ }^{1)}$ Data represent the mean \pm SD three replications.

${ }^{2)}(+)$-Catechin was used as a positive control.

${ }^{3)}$ Not detected 
Table 2. $\mathrm{ABTS}^{+}$radical scavenging activity of the methanolic extract of $A$ asphodeloides and its n-hexane, EtOAc-, $n$-BuOH-, and $\mathrm{H}_{2} \mathrm{O}$-soluble portions

\begin{tabular}{|c|c|c|c|c|c|c|c|}
\hline \multirow{2}{*}{ Conc. $(\mathrm{mg} / \mathrm{mL})$} & \multicolumn{6}{|c|}{ Scavenging activity $(\%)^{1)}$} & \multirow{2}{*}{$\begin{array}{c}\mathrm{IC}_{50} \\
(\mathrm{mg} / \mathrm{ml})\end{array}$} \\
\hline & 1000 & 500 & 250 & 125 & 62.5 & 31.3 & \\
\hline $70 \% \mathrm{MeOH}$ ext. & 82.2 & 77.3 & 68.7 & 48.6 & 31.1 & 19.9 & $137.3 \pm 9.5$ \\
\hline $\mathrm{n}$-Hexane layer & 55.8 & 44.8 & 33.3 & 26.1 & 14.3 & 9.6 & $704.5 \pm 40.1$ \\
\hline EtOAc layer & 100 & 99.2 & 94.8 & 86.1 & 74.4 & 55.0 & $20.5 \pm 1.7$ \\
\hline n-BuOH layer & 99.3 & 98.9 & 90.4 & 76.9 & 57.7 & 35.6 & $50.7 \pm 0.7$ \\
\hline $\mathrm{H}_{2} \mathrm{O}$ layer & 55.2 & 40.4 & 26.7 & 15.7 & 8.1 & 4.3 & $800.4 \pm 11.2$ \\
\hline (+)-Catechin ${ }^{2)}$ & 100 & 99.9 & 99.9 & 99.8 & 99.6 & 99.7 & $2.3 \pm 0.2$ \\
\hline
\end{tabular}

${ }^{1)}$ Data represent the mean \pm SD three replications.

${ }^{2)}$ Positive control.

의 $1000 \mathrm{mg} / \mathrm{ml}$ 농도에서는 $57.8 \%$ 의 $\mathrm{ABTS}^{+}$라디칼 소거능 을 나타냄을 알 수 있었으며, 각 분획물중에서도 특히 $\mathrm{EtOAc}$ 및 $\mathrm{n}-\mathrm{BuOH}$ 분획층이 $125 \mathrm{mg} / \mathrm{ml}$ 의 농도에서 $86.1 \%$ 및 $76.9 \%$ 의 매우 우수한 라디칼 소거능을 나타내었으며, positive control인 (+)-catechin의 활성에 상당하는 효능을 확인하였다. EtOAc 분획층의 $62.5 \mathrm{mg} / \mathrm{ml}$ 의 농도에서 $74.4 \%, 31.3 \mathrm{mg} / \mathrm{ml}$ 의 농도에서 $55.0 \%$ 의 라디칼 소거능을 나타내어 소거능의 농도 의존적 성향을 보였다. $\mathrm{H}_{2} \mathrm{O}$ 분획 층과 $\mathrm{n}$-Hexane 분획층에서는 거의 효능이 나타나지 않았 다. Table 4에서 나타낸 것처럼 총 페놀성 함량 상대적으로 높게 나타난 $\mathrm{EtOAc}, \mathrm{n}-\mathrm{BuOH}$ 층에 $\mathrm{ABTS}^{+}$라디칼 소거 활성 물질의 존재가 시사되었으며, 특히 EtOAc 층에 대해서 이 들 활성물질의 동정이 필요하다고 사료된다.

\section{Pancreatic lipase 저해활성}

Pancreatic lipase는 지방질 가수분해 효소로 triglyceride 의 에스테르결합을 가수분해시켜 glycerol과 fatty acid으로 분해한다. 섭취한 지방은 lipase의 작용에 의해 주로 monoglyceride와 fatty acid로 분해되어 담즙산염과 미셀을 형성해서 흡수된다. 흡수된 지방산은 소장상피세포에서 triglyceride로 재합성되어 순환혈액 속에 들어가고 간장, 지방조직, 근육 등으로 보내져 사용되고 남은 triglyceride는 각 조직에 축적된다. 이때 지방의 축적이 과도하면 비만을 초래할 수 있다. 지방 흡수의 중요한 역할을 하는 lipase의 활성저해를 통해 지방이 체내에 소화, 흡수 되지 않고 체외 로 배설되게 함으로 지방의 축척을 막을 수 있다. 현재 시판 중인 비만치료제로서 orlistat (상품명:xenical)은 triglyceride 를 분해하는 췌장의 지방분해 효소인 lipase에 비가역적인 결합을 하여 불활성화 시킴으로서 triglyceride 및 cholesterol의 흡수를 감소시킴과 동시에 배설 시키는 기작 으로 항비만 작용을 하지만 복부고통, 설사 등의 부작용이 문제시되고 있어(35), 이들 부작용이 없는 천연 항비만 소재 개발을 위한 연구가 활발하게 이루어지고 있다(19). 전통 약용식물로부터 항비만 선도물질개발을 목표로 하여 지모 의 $70 \%$ methanol 추출물을 극성에 따라 n-hexane, EtOAc, $\mathrm{n}-\mathrm{BuOH}$ 로 순차 분획하여 얻어진 각 분획에 대하여 pancreatic lipase를 이용한 실험을 통해 활성을 Table 3에 나타내었다. 그 결과 $\mathrm{EtOAc}$ 분획층의 $125 \mathrm{mg} / \mathrm{mL}$ 의 지방분 해효소에 대한 저해능은 $87.1 \%$ 의 비교적 강한 저해활성을 나타내었으며, 이 활성은 농도의존적 이었다.

Table 3. Inhibitory effects of the methanolic extract of $A$ asphodeloides and its n-hexane, EtOAc-, n-BuOH-, and $\mathrm{H}_{2} \mathrm{O}$-soluble portions against pancreatic lipase

\begin{tabular}{|c|c|c|c|c|c|c|c|}
\hline \multirow{2}{*}{ Conc. (mg/mL) } & \multicolumn{6}{|c|}{ Inhibition $(\%)^{1)}$} & \multirow{2}{*}{$\begin{array}{c}\mathrm{IC}_{50} \\
(\mathrm{mg} / \mathrm{ml})\end{array}$} \\
\hline & 1000 & 500 & 250 & 125 & 62.5 & 31.3 & \\
\hline $70 \% \mathrm{MeOH}$ ext. & 74.3 & 82.6 & 54.6 & 44.2 & 46.7 & -3) & $167.2 \pm 46.7$ \\
\hline $\mathrm{n}$-Hexane layer & - & - & - & - & - & - & $>1000$ \\
\hline EtOAc layer & 87.4 & 83.1 & 80.1 & 77.1 & 72.4 & 50.4 & $31.3 \pm 0.1$ \\
\hline $\mathrm{n}$-BuOH layer & 72.4 & 32.3 & 25.6 & 13.8 & 1.7 & 19.6 & $673.7 \pm 96.5$ \\
\hline $\mathrm{H}_{2} \mathrm{O}$ layer & 86.7 & 86.7 & 76.7 & 50.4 & 46.2 & 45,7 & $90.1 \pm 14.7$ \\
\hline Orlistat $^{2)}$ & 100 & 100 & 100 & 92.2 & 92.7 & 91.8 & $0.2 \pm 0.1$ \\
\hline
\end{tabular}

\footnotetext{
${ }^{1)}$ Data represent the mean \pm SD three replications.

${ }^{2)}$ Orlistat was used as a positive control.

${ }^{3)}$ Not detected
} 


\section{총페놀 화합물 함량}

지모 $70 \%$ methanol 추출물 및 각 분획물의 수율과 각각에 함유하고 있는 총페놀성 화합물의 함량을 Fig. 1과 Fig. 2에 차례로 나타내었다. 지모 $70 \%$ methanol 추출물의 경우 $28.3 \%$ 의 추출 수율과 $1 \mathrm{~g}$ 당 $13.4 \mathrm{mg}$ 의 페놀성 화합물을 함유 하는 것으로 나타나 새로운 생리활성 천연 소재로서 활용 가능성에 대해 더 많은 연구가 이루어질 필요성이 있는 것으로 사료된다. 또한 EtOAc 분획물이 $1 \mathrm{~g}$ 당 $19.1 \mathrm{mg}$ 의 페놀성 화합물을 함유하는 것으로 나타났으며, $\mathrm{n}-\mathrm{BuOH}$ 분 획물이 $17.6 \mathrm{mg}, \mathrm{H}_{2} \mathrm{O}$ 층에서는 $1 \mathrm{~g}$ 당 $4.2 \mathrm{mg}$ 의 페놀성 화합 물의 함량이 확인되었다. $\mathrm{n}$-hexane 분획물은 $3.0 \mathrm{mg}$ 의 상대 적으로 낮은 페놀 함류량을 나타내는 것으로 분석되었다.

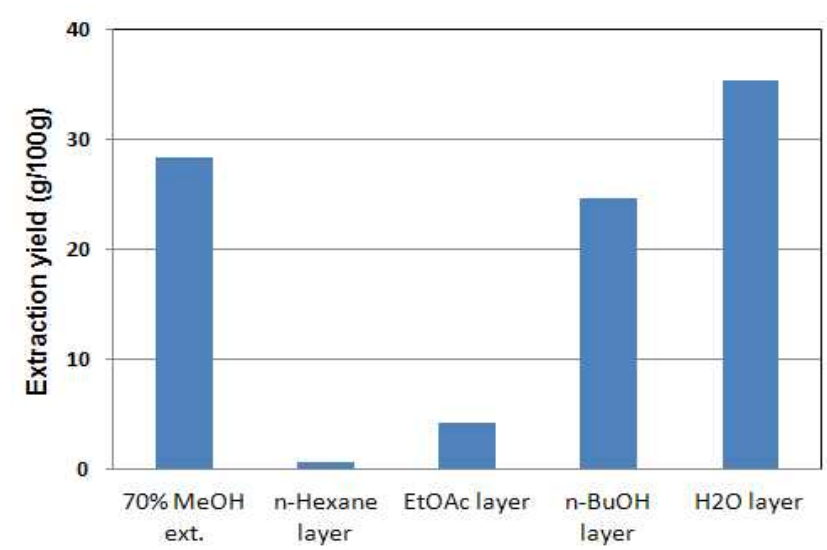

Fig. 1. Extraction yield of the methanolic extract and organic solvent fractions of $A$ asphodeloides

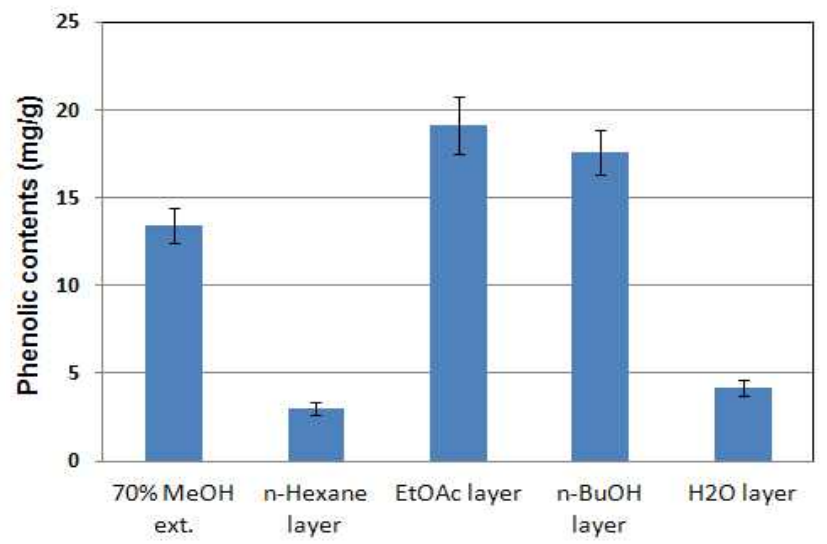

Fig. 2. Total phenolic contents of the methanolic extract and organic solvent fractions of $A$ asphodeloides Data represent the mean \pm SD three replications.

\section{요 약}

지모를 $70 \%$ methanol로 침지 추출하여 얻어진 추출물에 대해 n-hexane, EtOAc 및 n-BuOH로 순차 용매 분획하였고,
얻어진 결과물에 대하여 DPPH 및 $\mathrm{ABTS}^{+}$radical 소거능 및 pancreatic lipase 저해활성을 평가하였다. DPPH 라디칼 소거능은 페놀성 화합물의 함량이 상대적으로 높은 $\mathrm{n}-\mathrm{BuOH}$ 층의 $1000 \mathrm{mg} / \mathrm{ml}$ 의 시험농도에서는 $91.2 \%$ 의 라디 칼 소거능을 확인하였고, 지모 추출물에 존재하는 페놀성 화합물이 라디칼 소거능과의 연관성을 시사하였다. 또한 $\mathrm{ABTS}^{+}$라디칼 소거능은 $\mathrm{EtOAc}$ 층이 $\mathrm{IC}_{50}=20.5 \pm 1.7 \mathrm{mg} / \mathrm{ml}$, $\mathrm{n}-\mathrm{BuOH}$ 층이 $\mathrm{IC}_{50}=50.7 \pm 07 \mathrm{mg} / \mathrm{ml}$ 의 활성이 확인 되었고, 강한 활성물질의 존재가 시사되었다. 또한, pancreatic lipase 저해활성을 측정한 결과, 강한 $\mathrm{ABTS}^{+}$라디칼 소거능을 나 타낸 $\mathrm{EtOAc}$ 층의 $\mathrm{IC}_{50}$ 은 $31.3 \pm 0.1 \mathrm{mg} / \mathrm{ml}$ 의 저해율을 나타내 었으며 이는 대조군인 orlistat에 비해 약하나 단일물질로 정제할 경우 더욱 강한 효능의 화합물이 존재할 가능성이 있음을 보여준다. 오일의 형태로 얻어진 n-hexane 분획층은 항산화 활성 및 pancreatic lipase 저해 활성을 거의 나타내지 않았다. 향후 이들 활성물질 동정을 통한 활성 기작에 대한 연구가 필요하며 본 연구결과는 보다 우수한 라디칼 소거능 및 pancreatic lipase 저해능을 가지는 새로운 선도화합물 발굴을 위한 기초자료로 활용가능하리라 사료된다.

\section{감사의 글}

이 연구는 산업통상자원부·부산광역시 지원 지역혁신 센터사업(RIC08-06-07) 동의대학교 블루바이오 소재개발 및 실용화지원센터의 지원으로 이루어졌습니다.

\section{References}

1. Videla LA, Fermandez V (1988) Biochemical aspects of cellular oxidative stress. Arch Biol Med Exp, 21, 85-92

2. Halliwell B, Aruoma OJ (1991) DNA damage by oxygen-derived species. FEBS Lett, 281, 9-19

3. Jennings PE, Barnett AH (1988) New approaches to the pathogenesis and treatment of diabetic microangiopathy. Diabetic Med, 5, 111-117

4. Shim JS, Kim SD, Kim TS, Kim KN (2005) Biological activities of flavonoid glycosides isolated from Angelica keiskei. Korean J Food Sci Technol, 37, 78-83

5. Farag RS, Badei AZMA, Hewedi FM, EL-baroty GSA (1989) Antioxidant activity of some spice essential ols on linoleic acid oxidation in aqueous media. J American Oil Chem Soc, 66, 792-799

6. Frei B (1994) National antioxidants in human health and disease. Academic Press, San Diego, CA, USA, p 44-55

7. Branen AL (1975) Toxicology and biochemistry of butylated hydroxy anisole and butylated hydoxytoluane. 
J Oil Chem Soc, 52, 59-62

8. Masaki H, Sakaki S, Atsumi T, Sakurai H (1995) Active-oxygen scavenging activity of plants extracts. Biol Pharm Bull, 18, 162-166

9. Bray GA, Popkin BM (1998) Dietary fat intake dose affect obesity. Am J Clin Nutr, 68, 1157-1173

10. Bray GA, Popkin BM (1999) Dietary fat affects obesity rate. Am J Clin Nutr, 70, 572-573

11. Levinson ML (1977) Obesity and health. Prev Med, 6, $172-180$

12. Rexrode KM, Manson JE, Hennekens CH (1996) Obesity and cardiovascular disease. Curr Opin Cardiol, 11, 490-495

13. Sjostrom LV (1992) Morbidity of severely obese subjects. Am J Clin Nutr, 55, 508-515

14. Bitou N, Nimomiya M. Tsjita T, Okuda H (1999) Screening of lipase inhibitors from marine algae. Lipids, 34, 441-445

15. Drent ML, Larsson I, William-Olsson T, Quaade F, Czubayko F, Von Bergmann K, Strobel W, Sjotro L, Van der Veen EA (1995) Orlistat (RO 18-0647), a lipase inhibitor, in the treatment of human obesity: a multiple dose study. Int J Obesity, 19, 221-226

16. Hadvay P, Lengsfeld H, Wolter H (1988) Inhibition of pancreatic lipase in vitro by covalent inhibitor tetrahydrolipstatin. Biochem J, 256, 357-361

17. Peter C, Williams G (2001) Drug treatment of obesity: from past failures to future successes? $\mathrm{Br} \mathrm{J}$ Clin Pharmacol, 51, 135-141

18. Yamamoto M, Shimura S, Itoh Y, Ohsaka T, Egawa M, Inoue S (2000) Anti-obesity effects of lipase inhibitor CT-II, an extract from edible herbs, Nomame Herba, on rats fed a high-fat diet. Int J Obesity, 24, 758-764

19. Birari RB, Bhutani KK (2007) Pancreatic lipase inhibitors from natural sources: unexplored potential. Drug Dicov Today, 12, 879-889

20. Lee EM, Lee SS, Chung BY, Cho JY, Lee IC, Ahn SR, Jang SJ, Kim TH (2010) Pancreatic lipase inhibition by C-glucosidic flavones isolated from Eremochloa ophiuroides. Molecules, 15, 8251-8259

21. Hong JY, Shin SR, Bae MJ, Bae JS, Lee IC, Kwon OJ, Jung JW, Kim YH, Kim TH (2010) Pancreatic lipase inhibitors isolated from the leaves of cultivated mountain ginseng (Panax ginseng). Korean J Food Preserv, 17, 727-732

22. Duke JA (2002) Handbook of Medicinal Herbs, $2^{\text {nd }}$ ed, CRC Press, New York, USA, p 27-28

23. Pardo-Andreu GL, Sanchez-Baldoquin C, Avila- Gonzalez
R, Delgado R, Naal Z, Curti C (2006) Fe(III) improves antioxidant and cytoprotecting activities of mangiferin. Eur J Pharmacol, 547, 31-36

24. Iida Y, Oh KB, Saito M, Matsuoka H, Kurata H (2000) In vitro synergism between nyasol, an active compound isolated from Anemarrhena asphodeloides, and azole agents against Candida albicans. Planta Med, 66, 435-438

25. Park HJ, Lee JY, Moon SS, Hwang BK (2003) Isolation and anti-oomycete activity of nyasol from Anemarrhena asphodeloides rhizomes. Phytochemistry, 64, 997-1001

26. Nakashima N, Kimura I, Kimura M, Matsuura H (1993) Isolation of pseudoprototimosaponin AII from rhizomes of Anemarrhena asphodeloides and its hypoglycemic activity in streptozotocin induced diabetic mice. J Nat Prod, 56, 345-350.

27. Sy LK, Yan SC, Lok CN, Man RYK, Che CM (2008) Timosaponin A-III induces autophagy proceding mitochondria-mediated apoptosis in HeLa cancer cells. Cancer Res, 68, 10229-10237.

28. Ren LX, Luo YF, Li X, Zuo DY, Wu YL (2006) Antidepressant-like effects of sarsasapogenin from Anemarrhena asphodeloides BUNGE(Liliaceae). Biol Pharm Bull, 29, 2304-2306.

29. Blois MS (1958) Antioxidant activity determination by the use of a stable free radical. Nature, 181, 1199-1200

30. Re R, Pellegrini N, Proteggente A, Pannala A, Yang M, Rice-Evans C (1999) Antioxidnt activity applying and improved ABTS radical cation decolorization assay. Free Radic Biol Med, 26, 1231-1237

31. Kim JH, Kim HJ, Park HW, Youn SH, Choi DY, Shin CS (2007) Development of inhibitors against lipase and alpha-glucosidase from derivatives of monascus pigment. FEMS Microbiol Lett, 276, 93-98

32. Gao X, Bjor L, Trajkovski V, Uggla M (2000) Evaluation of antioxidant activities of rosehip ethanol extracts in different test system. J Sci Food Agri, 80, 2021-2027

33. Torel J, Gillard J, Gillard P (1986) Antioxidant activity of flavonoids and reactivity with peroxy radical. Phytochemistry, 25, 383-385

34. Wang SY, Chang HN, Lin KT, Lo CP, Yang NS, Shyur LF (2003) Antioxidant properties and phytochemical characteristics of extracts from Lactuca indica. J Agric Food Chem, 26, 1506-1512

35. Cooke D, Bloom S (2006) The obesity pipeline: current strategies in the development of anti-obesity drugs. Nat Rev Drug Discov, 5, 919-931

(접수 2014년 2월 27일 수정 2014년 5월 13일 채택 2014년 5월 16일) 